\title{
Insufficient choline intake during pregnancy: cohort study
}

\author{
Ingestão insuficiente de colina \\ durante a gestação: estudo de coorte
}

Caroline de Barros GOMES'1 (iD) 0000-0002-9576-4251

Maria Antonieta de Barros Leite CARVALHAES ${ }^{1,2}$ (iD) 0000-0002-6695-0792

A B S TRACT

\section{Objective}

To investigate the intake of choline during pregnancy and associated factors.

\section{Methods}

Cohort study with 353 pregnant women recruited from the primary health care network in an inland city of the State of São Paulo. In-house interviews were conducted in each of the gestational trimesters. In each of these points in time, a 24-hour dietary recall was collected. Subsequently, a new dietary recall collection was performed by telephone in the same trimester on a non-consecutive day, differentiating weekday versus weekend/holiday. Dietary intake data were included in the Nutrition Data System for Research software, and the habitual food intake throughout pregnancy was determined, with intra-individual variation correction in the MSM software. The influence of socioeconomic, obstetric and lifestyle factors, and of the actual diet, on choline intake during pregnancy was assessed using linear regression models, that were developed with the Stata software version 14.2, at a significance level of 95\%.

\section{Results}

Choline intake (281.1 \pm 68.6 milligrams) was below the recommended adequate intake, and only energy was positively associated with this micronutrient intake.

\section{Conclusion}

Choline intake in the population studied fell far short of current recommendations, and only higher energy intake was found as a factor associated with a higher intake.

Keywords: Choline. Food Consumption. Pregnant women. Prenatal nutrition.

\footnotetext{
${ }^{1}$ Universidade Estadual Paulista Júlio de Mesquita Filho, Faculdade de Medicina de Botucatu, Programa de Pós-Graduação em Saúde Coletiva. Av. Prof. Mário Rubens Guimarães Montenegro, s/n., Rubião Júnior, 18618-687, Botucatu, SP, Brasil. Correspondence to: C. B. GOMES. E-mail: <caroline.b.gomes@unesp.br>.
}

${ }^{2}$ Universidade Estadual Paulista Júlio de Mesquita Filho, Faculdade de Medicina de Botucatu, Departamento de Enfermagem. Botucatu, SP, Brasil.

How to cite this article

Gomes CB, Carvalhaes MABL. Insufficient choline intake during pregnancy: cohort study. Rev Nutr. 2021;34e:200187. https://doi. org/10.1590/1678-9865202134200187 


\section{RESUMO}

\section{Objetivo}

Investigar a ingestão de colina durante a gestação e fatores associados.

\section{Métodos}

Estudo de coorte com 353 gestantes recrutadas na rede de assistência primária à saúde de cidade paulista. Foram realizadas entrevistas presenciais, no domicílio, em cada um dos trimestres gestacionais. Em cada momento foi coletado um recordatório alimentar de 24 horas, seguido por nova coleta via telefone no mesmo trimestre, em dia não consecutivo, diferenciando dia de semana versus final de semanalferiado. Os dados de consumo alimentar foram incluídos no software Nutrition Data System for Research, sendo obtida a ingestão habitual, durante toda a gestação, com correção da variação intraindividual, no software MSM. A influência de fatores socioeconômicos, obstétricos, de estilo de vida e da própria dieta sobre a ingestão de colina na gestação foi avaliada por modelos de regressão linear, realizados no software Stata versão 14.2, ao nível de significância de 95\%.

\section{Resultados}

A ingestão diária de colina $(281,1 \pm 68,6$ miligramas) mostrou-se abaixo do recomendado, sendo que apenas a energia mostrou-se como positivamente associada à ingestão desse micronutriente.

\section{Conclusão}

A ingestão de colina na população estudada ficou muito aquém das recomendações atuais, sendo que apenas a maior ingestão energética foi encontrada como fator associado à maior ingestão de colina.

Palavras-chave: Colina. Ingestão de alimentos. Gestantes. Nutrição pré-natal.

\section{INTRODUCTION}

Choline (also known as vitamin B8) was only acknowledged as an essential nutrient in 1998, after researchers reported liver dysfunction in men consuming food withvery restricted content of this micronutrient, which was reversed with supplementary administration [1]. Further studies demonstrated that the endogenous pathway of choline production (PEMT- Phosphatidylethanolamine N-methyltransferase) is not enough to meet the needs of all individuals, men in particular. Women are less vulnerable to choline deficiency, due to the effect of estrogen that works favorably by stimulating the endogenous pathway PEMT [2].

However, during pregnancy, the protection provided by estrogen is not sufficient in view of the increased choline demand. The repercussions of a low choline intake during pregnancy have shown to be important, influencing the baby's brain development and the occurrence of birth defects $[2,3]$. The choline Recommended Daily Intake (RDI) during pregnancy is estimated at 450 milligrams [1].

Choline is a precursor of the phospholipids necessary for cell division, growth and proper functioning of the cell membrane receptors, brain development and neurotransmission [3,4]. Literature shows unfavorable effects due to low choline intake during pregnancy such as defects in the neural tube and impairment of brain development and its functions [3,5]. Still with regard to the fetus, choline can offer protection from problems, such as those resulting from maternal alcohol use [6]. In vitro, it has been shown that the lack of choline in pregnancy affects the development of the placenta by reducing angiogenesis [7]. At one year of age, children of mothers affected by common infections during pregnancy but with higher levels of gestational choline showed better development of behavioral self-regulation, closer to the level of children born out of mothers who suffered no infection [8].

Eggs, milk and meat can be considered good sources of choline, while foods of plant origin contain a very low amount of this micronutrient $[9,10]$. Eating daily two large eggs provide $65.3 \%$ of the current choline daily recommendation [11]. 
Despite the importance of this micronutrient intake during pregnancy, studies that have assessed choline intake during this period are rare. Regarding the choline dietary intake, American pregnant women evaluated in 2004-2005 ingested an average of 319 milligrams/day and only $8.51 \%$ of pregnant women had an intake higher than the RDI [12]. Among South African pregnant women, the average choline intake values were between 250 to $340 \mathrm{mg} /$ day [13]. To date, no investigation with Brazilian pregnant women has been published. This article presents the results of the evaluation of choline dietary intake in a cohort of Brazilian pregnant women and the investigation of the factors associated with such intake.

\section{METHODS}

Cohort study that used the data of an investigation called "Impact of intervention to promote leisure walking and healthy eating in pregnant women attended by the Family Health Strategy: a controlled cohort study", carried out in 2013/14. The objective of this parent study was to evaluate the impact of walking practice during leisure and on the eating practices of pregnant women after a continuing education action implemented with those responsible for prenatal care in the primary health care network in the municipality of Botucatu, in the inland region of the State of São Paulo. This is a municipality located in the south-central region of the State of São Paulo, $235 \mathrm{~km}$ from the capital, with a territorial area of 1,482,642km², which had, at the beginning of the data collection, approximately 130,201 inhabitants; the infant mortality rate was 4,512.20 deaths/100 thousand live births, HDI 0.800, with a population predominantly urban (93\%).

Details of this parent study have been reported in a previous publication [14]. In summary, two groups of pregnant women were monitored: cohort A, composed of pregnant women attended at the nine Family Health Units (USFs) in the city of Botucatu and accompanied by doctors and nurses who participated in educational activities and cohort B, composed of pregnant women attended at the eight Basic Health Units (UBSs), monitored by doctors who did not participate in educational activities. The dietary practices addressed in the educational action consisted in promoting the consumption of three fruits daily, two servings of vegetables and beans in the two main meals, at least five days a week, and the incorporation of advice to avoid consumption of soft drinks or industrialized biscuits or consume them only sporadically. The promotion of physical activity included walking at leisure at least five days a week.

The present study followed the same inclusion criteria of the parent study (pregnant women enrolled in public prenatal care programs for primary health care in the municipality, between November 2012 and June 2013, aged over 18 and in the $1^{\text {st }}$ gestational trimester) and the same exclusion criteria (twinning, presence of factors that would cause high riskin prenatal care), conducting only one a posteriori data analysis. The sample size designed for the original study was 280 pregnant women, 140 in each group/ cohort, a sample size necessary to detect differences in the proportions of pregnant women who performed the recommended leisure walk in the third trimester of $5 \%$ to $15 \%$, with a $5 \%$ significance level and $80 \%$ power. In addition, 15\% were added for multiple statistical analyses and $10 \%$ for possible follow-up losses. The minimum sample size also allowed detecting changes in the diet from 40 to $50 \%$.

Interviews were conducted, in each gestational trimester, by a previously trained staff, in each pregnant woman's home; in the $1^{\text {st }}$ gestational trimester, 353 pregnant women were interviewed. Only $3.0 \%$ of pregnant women refused to continue participating in the study which, added to some follow-up losses (changes in the prenatal location, change to private health services or change to a reference hospital for high-risk pregnancies, moved to a different location and abortions), 281 pregnant women were assessed in the second trimester and 267 in the $3^{\text {rd }}$ trimester (Figure 1).

In each face-to-face interview, data were collected about the course of pregnancy, highlighting the first interview that also included the collection of sociodemographic, lifestyle and obstetric data. The variables from this interview used in this study were: age (21 |- 34 years, 18 to 20 years, 35 |- years), 


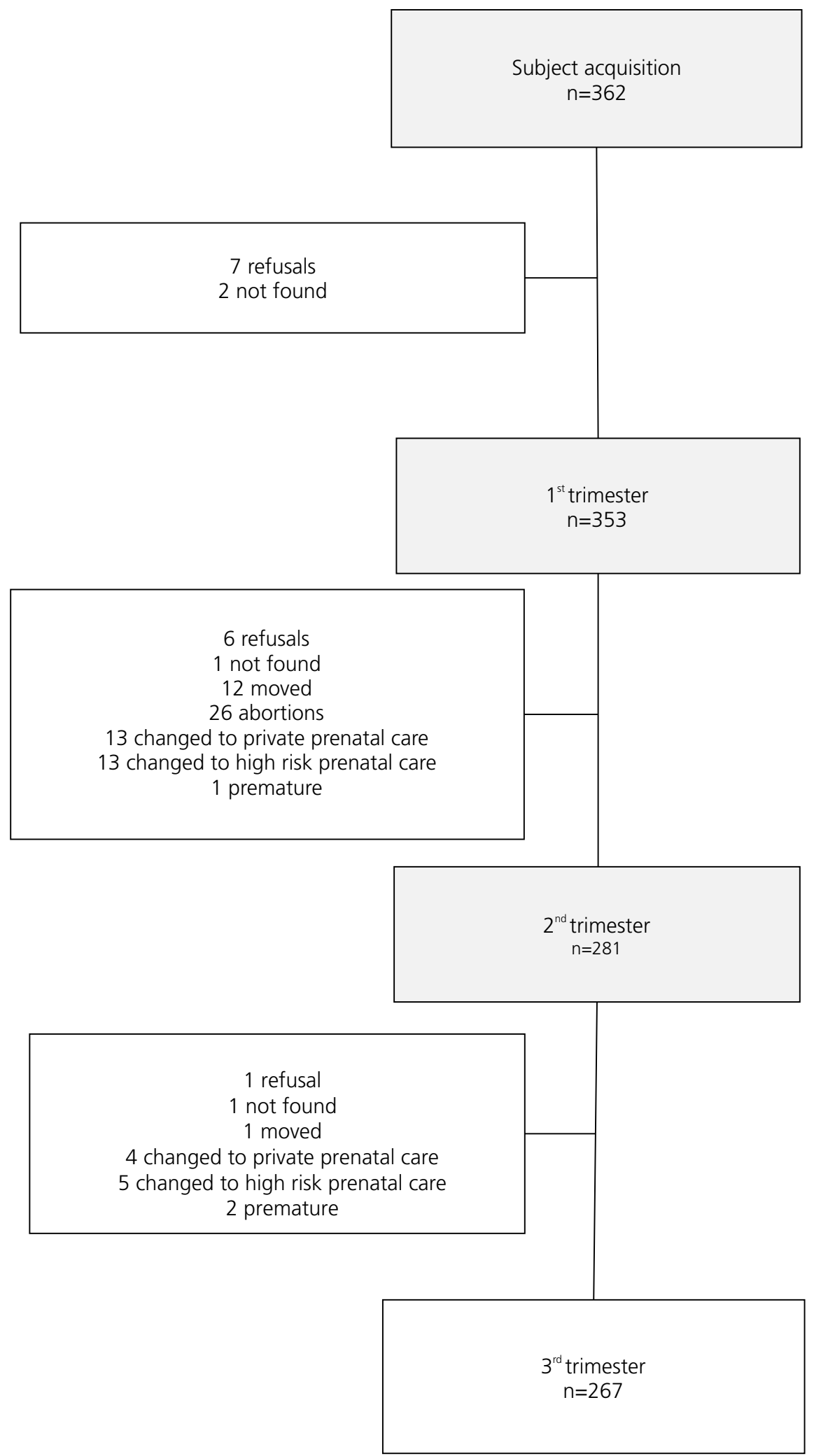

Figure 1 - Flowchart of pregnant women participating in the study. Botucatu (SP), Brazil, 2012-2014. 
education ( $\geq 11$ years of study, $8 \mid-11$ years of study, $<8$ years of study), socioeconomic classification (class $B$, class $C$, class D/E), working outside home (yes, no), living with a partner (yes no), parity $(0,1,2$ or more deliveries), self-reported skin color (white, not white), pre-gestational tobacco use (yes, no), pre-gestational alcohol use (yes, no) and walking during leisure (yes, no). The pre-gestational BMI variable was also used, which characterizes the nutritional status of women before pregnancy ;women were classified as low weight, normal weight (eutrophy), overweight or obesity [15]. For the composition of this variable, weight and height were obtained from the pregnant women's medical records in each health unit where each pregnant woman performed her prenatal care. Pre-gestational weight was considered the weight recorded before the woman became pregnant, or the first weight measured in the $1 \mathrm{st}$ gestational trimester, if $\pm 2.0 \mathrm{~kg}$ different from the pre-gestational weight.

The outcome variable of this study is the intake of dietary choline throughout pregnancy. To this end, the food consumption data originated from six 24-hour food recall (R24h), two of them applied in each trimester of pregnancy, the first one in the interview conducted at home and the second one, on a day not consecutive with the first one, by telephone. The R24h were applied using the Multiple Pass Method, which contributes to obtain a greater accuracy of the information collected [16]. All R24h foods and preparations were then standardized and quantified in grams or milliliters according to the Brazilian homemade measurement tables and, later, included in the Nutrition Data System for Research (NDSR) software, version 2010 [17]. Periodic consistency analyses were performed when entering data. R24h with energy intake higher than $6000 \mathrm{kcal}$ or lower than $600 \mathrm{kcal}$ were excluded and the choline intake was obtained using the actual NDSR software [18]. The usual choline intake during pregnancy for each pregnant woman, with the correction of intra-individual variability, was obtained with the MSM software.

Initially, descriptive analyses were performed with the exposure and outcome variables. The difference between the intake means according to the characteristics of the pregnant women was tested by ANOVA. The analyses of difference between the consumption averages in the different trimesters were tested by the paired t-test. The normality of the outcome variable was tested by the Kolmogorov-Sminorv test and by analyzing the intake distribution histogram. None of the practices addressed in the educational action was aimed at promoting choline sources, so that the pregnant women were grouped and considered as a single cohort in the analyses of this study. However, considering the hypothesis that eventually the pregnant women could differ in terms of choline intake due to the fact that they were assisted in prenatal care by professionals with different training in the promotion of healthy eating practices, the variable belonging to cohort A or B was inserted in the analyses, so that its potential role on choline intake could be controlled.

Linear regression analysis between choline intake and exposure variables were performed, with the initial adjustment by cohort, and those with $p<0.25$ were included together and maintained in a multiple model. All analyses were performed using the Stata software version 14.2 , considering $p<0.05$ as the level of statistical significance.

At the time of the first home interview, all pregnant women were informed about the study and signed the free and informed consent form for their participation. This study was conducted in accordance with the guidelines of the Declaration of Helsinki and was approved by the Ethics Committee of the Botucatu Medical School (CAAE: 32407314.0.0000.5411- Opinion number: 1.526.510).

\section{RESULTS}

The pregnant women assessed belonged mostly to the socioeconomic class C (66.6\%), had 11 years or more $(49.3 \%)$ education and were caucasian (64.3\%). Almost half worked outside their home (48.2\%) and about $74 \%$ lived with a partner. More than half of them were in their second pregnancy or further pregnancies (57.8\%) and $47 \%$ had pre-pregnancy overweight. Choline intake differed only in relation to the parity of pregnant women (Table 1). 
Table 1 - Choline intake (milligrams), according to socioeconomic, demographic, obstetric characteristics and nutritional status of pregnant women ( $n=353)$. Botucatu (SP), Brazil, 2012-2014.

\begin{tabular}{|c|c|c|c|c|c|}
\hline \multirow{2}{*}{ Characteristics } & \multicolumn{2}{|c|}{ Frequency } & \multicolumn{2}{|c|}{ Intake (mg) } & \multirow{2}{*}{$p^{d}$} \\
\hline & N & $\%$ & Mean & SD & \\
\hline Age (years) & & & & & 0.987 \\
\hline 18 to 20 & 85 & 24.1 & 282.0 & 74.2 & \\
\hline $21 \mid-34$ & 238 & 67.4 & 280.9 & 65.0 & \\
\hline $35 \mid$ - and more & 30 & 8.5 & 280.0 & 81.3 & \\
\hline Education (years of passing grade) & & & & & 0.132 \\
\hline$\geq 11$ years & 174 & 49.3 & 288.3 & 62.5 & \\
\hline $8 \mid-11$ years & 102 & 28.9 & 271.7 & 73.1 & \\
\hline$<8$ years & 77 & 21.8 & 277.3 & 74.5 & \\
\hline Socioeconomic classification ${ }^{a}$ & & & & & 0.352 \\
\hline B & 34 & 9.9 & 278.6 & 61.8 & \\
\hline C & 235 & 68.1 & 286.0 & 69.0 & \\
\hline$D / E$ & 76 & 22.0 & 273.3 & 69.0 & \\
\hline Works outside home & & & & & 0.300 \\
\hline Yes & 170 & 48.2 & 285.0 & 67.1 & \\
\hline No & 183 & 51.8 & 277.4 & 69.9 & \\
\hline Lives with partner & & & & & 0.375 \\
\hline Yes & 261 & 73.9 & 279.8 & 67.4 & \\
\hline No & 92 & 26.1 & 284.9 & 71.9 & \\
\hline Number of deliveries & & & & & 0.032 \\
\hline 0 & 149 & 42.2 & 286.0 & 69.0 & \\
\hline 1 & 98 & 27.8 & 289.4 & 73.0 & \\
\hline 2 or more deliveries & 106 & 30.0 & 266.7 & 61.9 & \\
\hline White skin color ${ }^{b}$ & & & & & 0.814 \\
\hline Yes & 225 & 64.3 & 282.8 & 69.3 & \\
\hline No & 125 & 35.7 & 281.0 & 65.4 & \\
\hline Pre-gestational nutritional status ${ }^{c}$ & & & & & 0.491 \\
\hline Low weight & 17 & 5.0 & 301.5 & 66.0 & \\
\hline Eutrophy & 162 & 47.9 & 282.9 & 64.5 & \\
\hline Overweight & 97 & 28.7 & 285.9 & 73.5 & \\
\hline Obesity & 62 & 18.4 & 274.5 & 66.5 & \\
\hline Pre-gestational tobacco use & & & & & 0.500 \\
\hline No & 263 & 74.5 & 282.6 & 66.1 & \\
\hline Yes & 90 & 25.5 & 276.9 & 75.6 & \\
\hline Pre-gestational alcohol use & & & & & 0.945 \\
\hline No & 217 & 61.5 & 280.9 & 70.1 & \\
\hline Yes & 136 & 38.5 & 281.4 & 66.4 & \\
\hline Walks regularly during pregnancy & & & & & 0.371 \\
\hline Yes & 85 & 24.1 & 287.0 & 69.2 & \\
\hline No & 268 & 75.9 & 279.3 & 68.4 & \\
\hline
\end{tabular}

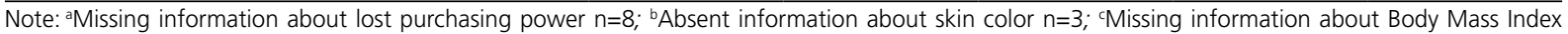
$\mathrm{n}=15$; 'One-Way ANOVA.

The average energy intake during pregnancy was 1876.5 (SD=416.1) kcal. The average choline intake was 281.1 (SD=68.6) $\mathrm{mg}$, with a minimum intake of $84.0 \mathrm{mg}$ and a maximum intake of 533.0mg. Only five pregnant women showed consumption above the RDI (1.4\%). Analyzing this consumption separately, pregnant women consumed, on average, 266.5 (SD=78.9) mg, 297.0 (SD=57.9) mg and 288.2 (SD=60.4) $\mathrm{mg}$ in the first, second and third gestational trimesters, respectively, and consumption was statistically different $(p<0.05)$ between the first and second trimester and between the first and third trimester (data not shown in tables). 
The main source of choline was beef, which provided $20.4 \%$ of the total choline present in all food recalls made with pregnant women throughout the gestational trimesters, followed by milk, chicken, legumes, eggs, pork, liver, fish, broccoli and kale (Table 2).

Crude regression analysis (with adjustment by the cohort) showed differences in choline intake according to total energy consumption $(p<0.001)$, with education and number of deliveries being potentially confounding factors $(0.25>p>0.05)$. The results of the multiple analysis showed that only energy intake was associated with choline intake, and with each $1 \mathrm{kcal}$ increment, choline intake increased $0.13 \mathrm{mg}$ (Table 3).

Table 2 - Main food sources of choline consumed by pregnant women. Botucatu, SP, Brasil, 2012-14.

\begin{tabular}{lc}
\hline Food & $\boldsymbol{\%}^{\mathbf{1}}$ \\
\hline Beef & 20.4 \\
Milk & 10.3 \\
Chicken meat & 8.6 \\
Legumes & 7.3 \\
Eggs & 4.1 \\
Pork meat & 2.8 \\
Liver & 2.2 \\
Fish & 1.0 \\
Broccoli and kale & 0.5 \\
\hline
\end{tabular}

Note: 'In relation to the total choline consumed in all R24h.

Table 3 - Results of the crude and multiple linear regression analysis, between maternal characteristics and choline intake, during pregnancy.

\begin{tabular}{|c|c|c|c|c|c|c|}
\hline \multirow{2}{*}{ Characteristics } & \multicolumn{3}{|c|}{ Crude analysis $^{1}$} & \multicolumn{3}{|c|}{ Multiple analysis ${ }^{1}$} \\
\hline & $\beta$ & $95 \% \mathrm{Cl}$ & $p$ & $\beta$ & $95 \% \mathrm{Cl}$ & $p$ \\
\hline Total energy & 0.13 & $0.12 ; 0.14$ & $<0.001$ & 0.13 & $0.12 ; 0.14$ & $<0.001$ \\
\hline Age (years) & 0.17 & $-1.04 ; 1.39$ & 0.773 & & & \\
\hline Education (years of passing grade) & 1.60 & $-1.00 ; 4.19$ & 0.227 & 0.66 & $-1.07 ; 2.40$ & 0.453 \\
\hline Socioeconomic classification & -5.36 & $-18.54 ; 7.82$ & 0.424 & & & \\
\hline Works outside home & -7.59 & $-21.97 ; 6.79$ & 0.300 & & & \\
\hline Lives with partner & 5.10 & $-11.28 ; 21.48$ & 0.541 & & & \\
\hline Number of deliveries & -4.99 & $10.53 ; 0.55$ & 0.077 & 1.07 & $-2.56 ; 4.69$ & 0.564 \\
\hline White skin color & 1.79 & $-16.70 ; 13.12$ & 0.814 & & & \\
\hline Pre-gestational BMI & 0.09 & $-1.20 ; 1.38$ & 0.887 & & & \\
\hline Pre-gestational tobacco use & -5.66 & $-22.15 ; 10.83$ & 0.500 & & & \\
\hline Pre-gestational alcoholuse & 0.52 & $-14.27 ; 15.30$ & 0.945 & & & \\
\hline Walks regularly during pregnancy & -7.69 & $-24.56 ; 9.18$ & 0.371 & & & \\
\hline
\end{tabular}

Note: ${ }^{1}$ Cohort adjustment.

\section{DISCUSSION}

According to the literature searches that we carried out, this is the first Brazilian study to report data on the intake of choline in pregnant women. The intake in the cohort studied in Botucatu, SP was lower $(281.1 \mathrm{mg})$ than the recommendation of $450 \mathrm{mg} /$ day and the percentage of pregnant women who met the RDI was extremely low (1.4\%).

Among Canadian pregnant women, monitored during pregnancy and lactation, the average daily intake of choline during pregnancy was $337.8 \mathrm{mg}$, with 18\% meeting theRDI [19].Lower intake values, but still higher than those of Brazilian pregnant women, were found in American pregnant women, as already mentioned, with an average intake of $319 \mathrm{mg}$ and with $8.51 \%$ of pregnant women with an intake above the recommendation [12].The choline intake range of pregnant women in South Africa, also previously 
mentioned, is close to that of Brazilian pregnant women: between 250 and 340mg/day [13]. These results deserve the attention of professionals who assist pregnant women and of those who develop food and nutrition policies, since a high percentage of pregnant women do not meet the recommended intake, exposing themselves and their conceptions to many adverse events, such as those previously mentioned.

The situation of the pregnant women studied does not seem to be a particular feature of the place where the present study was conducted. Considering that studies in developed countries had already detected an inadequate situation for most of their pregnant women, a high prevalence of insufficient intake could be expected. The local and international picture may be even more serious, as the recommendation for choline intake during pregnancy is being challenged, with some investigators indicating that those recommendations are likely to be below the actual requirements, since doses well above the RDI have been associated with several beneficial effects [20].

The results of this study indicate that choline deficiency may be another relevant nutritional deficiency to affect the maternal and child populations in Brazil, although further studies are needed in other frameworks to provide evidence whether the conditions found in the location of this study are also equivalent in other country's locations. Among the nutritional deficiencies that are already acknowledged as being prevalent in the Brazilian maternal and child population are iron and folate deficiency, both of which are considered public health problems in Brazil and are included in individual and collective programs and interventions [21-23]. However, the low intake of choline during pregnancy does not appear as a public health problem or as a concern and there are no specific actions by the Brazilian health authorities to deal with it, a fact that is expected to be modified with the advent of new evidence.

In developed countries, where poor choline intake is already a concern of the health authorities, clinical trials have been conducted to assess the effectiveness of choline supplementation during pregnancy on obstetric, neonatal and childhood outcomes [20,24,25]. However, the way of coping with low choline intake using medication supplementation for pregnant women does not seem to be the best option for Brazil. Considering that the food route is viable and of relatively low cost, recommendations for the daily intake of food choline would be an action more in line with the National Food and Nutrition Policy and the Dietary Guidelines for the Brazilian Population [26].

On the other hand, the results found, revealed only a positive association between energy intake and choline intake. However, encouraging energy intake increase as a way to meet choline recommendations does not seem to be an appropriate strategy. Energy intake is positively associated with gestational weight gain[15]and the prevalence of excessive weight gain is increasing in Brazil and worldwide, being associated with adverse maternal and child health outcomes, such as increased risk for diabetes and gestational hypertension, big babies for their gestational age, macrosomia, cesarean delivery and higher postpartum weight retention rates $[15,27]$.

Thus, it is necessary to think about stimulating consumption of foods that are sources of choline, especially those with less energy input. As already pointed out, the consumption of two eggs already exceeds half of the choline RDI; it is a food that does not have a high energy density if prepared without oils/ fats $[11,28]$. An American study found that adults over 19 who consumed eggs were more likely to reach adequate choline RDI compared to non-consumers. Egg consumers ingested almost twice the usual choline amounts compared to non-consumers [12]. Another significant food source is liver; however, this food contains a high amount of vitamin $A$, which makes its daily intake inadequate due to the risk of exceeding the maximum limit of vitamin A tolerance [28].

Stimulating consumption of eggs as a way to improve the nutrition of children and mothers in low and middle income countries has been advocated by researchers in recent articles $[11,29]$. For these authors, eggs advantage over drug supplementation derives from the widespread recognition and acceptance of eggs as a human food and its high nutritional value, capable of providing, in addition to choline, other 
important nutrients such as high-quality proteins, essential fatty acids, cholesterol, vitamin A and carotenoids, among other ingredients. For pregnant women, in addition to providing more than half of the daily choline requirements, two eggs provide $1.7 \%$ of protein and between 20 to $35 \%$ of vitamins A, riboflavin, vitamin B12, pantothenic acid and phosphorus [28]. However, in the cohort assessed in this study, the eggs ranked third as source of choline, behind meat ( $\left.1^{\text {st }}\right)$ and milk and milk products $\left(2^{\text {nd }}\right)$. It is worth pointing out that this same population already had the dietary patterns investigated during pregnancy and in none of the three identified patterns eggs were present [30].

From a cultural point of view, the widespread concern with eggs' high cholesterol content and their potential cause of food poisoning, when undercooked, may cause pregnant women and health professionals suppose that it is not a healthy and safe food in this life stage. However, such claims are at odds with current Brazilian recommendations and that of many scholars of maternal and child nutrition $[11,26]$. In addition, the consumption of eggs was inversely associated with the consumption of ultra-processed foods [31]. There is also an association with the egg being a simpler, normal and day-to-day food, such as rice-beansegg-steak, a fact that also has to be considered when implementing the guidelines [32].

The validity of the results of this study is supported by the fact that six 24-hour food recall surveys were carried out during pregnancy and the adoption of the Multiple pass method technique, accepted as the best way to minimize the survey's respondents' memory's failures [16]. However, it is important to consider that the cohort was made up of pregnant women, users of the public network of the primary health care units and that, although they correspond to about $70 \%$ of the population in the locality, care should be taken in extrapolating the results to the population as a whole, even though a large portion of Brazilian pregnant women undergo prenatal care in the public health system [33]. Studies in other geographic, cultural and socioeconomic contexts are necessary so that the national scenario regarding the intake of choline in food by pregnant women be better known and, that actions to promote choline iintake be outlined.

One can also consider as a limitation of this study the use of international tables to assess the consumption of Brazilian pregnant women. However, the software involved is one of the most used in the world in food consumption analyses; in addition, there is a lack of choline quantification in national tables.

\section{CONCLUSION}

Choline intake among Brazilian pregnant women who are assisted by the public primary health care network was well below the recommendations. Given the important role of choline during pregnancy, stimulating the consumption of food sources of this micronutrient is a relevant strategy in prenatal care.

\section{CONTRIBUTORS}

CB Gomes and MABL Carvalhaes participated in the conception and design, analysis and interpretation of data, writing, revision and approval of the final version of the article.

\section{REFERENCES}

1. Institute of Medicine (United States). Dietary reference intakes for thiamin, riboflavin, niacin, vitamin b6, folate, vitamin b12, pantothenic acid, biotin, and choline. Washington: National Academies Press; 1998. https://doi. org/10.17226/6015

2. Zeisel S. Choline, other methyl-donors and epigenetics. Nutrients. 2017;9:445. https://doi.org/10.3390/nu9050445 
3. Korsmo HW, Jiang X, Caudill MA. Choline: exploring the growing science on its benefits for moms and babies. Nutrients. 2019;11:1823. https://doi.org/10.3390/nu11081823

4. Blusztajn JK, Slack BE, Mellott TJ. Neuroprotective actions of dietary choline. Nutrients. 2017;9:815. https://doi. org/10.3390/nu9080815

5. Li K, Wahlqvist M, Li D. Nutrition, one-carbon metabolism and neural tube defects: a review. Nutrients. 2016;8:741. https://doi.org/10.3390/nu8110741

6. Jacobson SW, Carter RC, Molteno CD, Stanton ME, Herbert JS, Lindinger NM, et al. Efficacy of maternal choline supplementation during pregnancy in mitigating adverse effects of prenatal alcohol exposure on growth and cognitive function: a randomized, double-blind, placebo-controlled clinical trial. Alcohol Clin Exp Res. 2018;42:132741. https://doi.org/10.1111/acer.13769

7. McGee M, Bainbridge S, Fontaine-Bisson B. A crucial role for maternal dietary methyl donor intake in epigenetic programming and fetal growth outcomes. Nutr Rev. 2018;76:469-78. https://doi.org/10.1093/nutrit/nuy006

8. Freedman R, Hunter SK, Law AJ, Wagner BD, D'Alessandro A, Christians U, et al. Higher gestational choline levels in maternal infection are protective for infant brain development. J Pediatr. 2019;208:198-206.e2. https://doi. org/10.1016/j.jpeds.2018.12.010

9. Wiedeman A, Barr S, Green T, Xu Z, Innis S, Kitts D. Dietary choline intake: current state of knowledge across the life cycle. Nutrients. 2018;10:1513. https://doi.org/10.3390/nu10101513

10. Wallace TC, Blusztajn JK, Caudill MA, Klatt KC, Natker E, Zeisel SH, et al. Choline: the undersconsumed and underappreciated essential nutrient. Nutr Today. 2018;53:240-53. https://doi.org/10.1097/NT.0000000000000302

11. Lutter CK, lannotti LL, Stewart CP. The potential of a simple egg to improve maternal and child nutrition. Matern Child Nutr. 2018;14:e12678. https://doi.org/10.1111/mcn.12678

12. Wallace T, Fulgoni V. Usual choline intakes are associated with egg and protein food consumption in the United States. Nutrients. 2017;9:839. https://doi.org/10.3390/nu9080839

13. Carter RC, Jacobson SW, Booley S, Najaar B, Dodge NC, Bechard LJ, et al. Development and validation of a quantitative choline food frequency questionnaire for use with drinking and non-drinking pregnant women in Cape Town, South Africa. Nutr J. 2018;17:108. https://doi.org/10.1186/s12937-018-0411-5

14. Malta MB, Carvalhaes MABL, Takito MY, Tonete VLP, Barros AJD, Parada CMGL, et al. Educational intervention regarding diet and physical activity for pregnant women: changes in knowledge and practices among health professionals. Bmc Pregnancy Childbirth. 2016;16:175. https://doi.org/10.1186/s12884-016-0957-1

15. Institute of Medicine; National Research Council (United States). Weight gain during pregnancy: reexamining the guidelines. Washington: The National Academies Press; 2009.

16. Moshfegh AJ, Rhodes DG, Baer DJ, Murayi T, Clemens JC, Rumpler WV, et al. The US Department of Agriculture Automated Multiple-Pass Method reduces bias in the collection of energy intakes. Am J Clin Nutr. 2008;88:324-32. https://doi.org/10.1093/ajcn/88.2.324

17. Nutrition Coordinating Center. Nutrition Data System for Research Software 2019. Minnesota: University of Minnesota; 2019 [cited 2020 Jan 7]. Available from: http://www.ncc.umn.edu/products/

18. Oken E, Kleinman KP, Olsen SF, Rich-Edwards JW, Gillman MW. Associations of seafood and elongated n-3 fatty acid intake with fetal growth and length of gestation: results from a US pregnancy cohort. Am J Epidemiol. 2004;160:774-83. https://doi.org/10.1093/aje/kwh282

19. Moore CJ, Perreault M, Mottola MF, Atkinson SA. Diet in early pregnancy: focus on folate, vitamin b12, vitamin d, and choline. Can J Diet Pract Res. 2020;81:58-65. https://doi.org/10.3148/cjdpr-2019-025

20. Caudill MA, Strupp BJ, Muscalu L, Nevins JEH, Canfield RL. Maternal choline supplementation during the third trimester of pregnancy improves infant information processing speed: a randomized, double-blind, controlled feeding study. Faseb J. 2018;32:2172-80. https://doi.org/10.1096/fj.201700692RR

21. Magalhães EIS, Maia DS, Pereira Netto M, Lamounier JA, Rocha DS. Prevalência de anemia e determinantes da concentração de hemoglobina em gestantes. Cad Saúde Coletiva. 2018;26:384-90. https://doi.org/10.1590/1414$462 \times 201800040085$

22. Barnabé A, Aléssio ACM, Bittar LF, Moraes Mazetto B, Bicudo AM, Paula EV, et al. Folate, vitamin b12 and homocysteine status in the post-folic acid fortification era in different subgroups of the Brazilian population attended to at a public health care center. Nutr J. 2015;14:19. https://doi.org/10.1186/s12937-015-0006-3 
23. Ministério da Saúde (Brasil). Atenção ao pré-natal de baixo risco. Brasília: Ministério; 2012.

24. Klatt KC, McDougall MQ, Malysheva OV, Brenna JT, Robertson MS, Caudill MA. Reproductive state and choline intake influence enrichment of plasma lysophosphatidylcholine-DHA: a post-hoc analysis of a controlled feeding trial. Br J Nutr. 2020;123:120. https://doi.org/10.1017/S0007114519003003

25. Jacobson SW, Carter RC, Molteno CD, Meintjes EM, Senekal MS, Lindinger NM, et al. Feasibility and acceptability of maternal choline supplementation in heavy drinking pregnant women: a randomized, double-blind, placebocontrolled clinical trial. Alcohol Clin Exp Res. 2018;42:1315-26. https://doi.org/10.1111/acer.13768

26. Ministério da Saúde (Brasil). Guia alimentar para a população brasileira. Brasília: Ministério; 2014.

27. Goldstein RF, Abell SK, Ranasinha S, Misso M, Boyle JA, Black MH, et al. Association of gestational weight gain with maternal and infant outcomes. Jama. 2017;317:2207. https://doi.org/10.1001/jama.2017.3635

28. Núcleo de Estudos e Pesquisas em Alimentação. Tabela Brasileira de Composição dos Alimentos. 4a. ed. Campinas: Universidade Estadual de Campinas; 2011.

29. Lutter CK, Morris SS. Eggs: a high potential food for improving maternal and child nutrition. Matern Child Nutr. 2018;14:e12666. https://doi.org/10.1111/mcn.12666

30. Gomes CB, Malta MB, Papini SJ, Benício MHDA, Corrente JE, Carvalhaes MABL. Adherence to dietary patterns during pregnancy and association with maternal characteristics in pregnant Brazilian women. Nutrition. 2019;62:85-92. https://doi.org/10.1016/j.nut.2018.10.036

31. Louzada ML da C, Martins APB, Canella DS, Baraldi LG, Levy RB, Claro RM, et al. Ultra-processed foods and the nutritional dietary profile in Brazil. Rev Saúde Pública. 2015;49. https://doi.org/10.1590/S00348910.2015049006132

32. Rocha ARC, da Rocha A, Rocha E. Classifying and classified: an interpretive study of the consumption of cruises by the "new" Brazilian middle class. Int Bus Rev. 2016;25:624-32. https://doi.org/10.1016/j.ibusrev.2015.02.006.

33. Leal MDC, Szwarcwald CL, Almeida PVB, Aquino EML, Barreto ML, Barros F, et al. Saúde reprodutiva, materna, neonatal e infantil nos 30 anos do Sistema Único de Saúde (SUS). Ciênc Saúde Coletiva. 2018;23:1915-28. https:// doi.org/10.1590/1413-81232018236.03942018 